\title{
Ocena obiektów cebuli (Allium cepa L.) pod względem tolerancji na suszę w fazie kiełkowania i wzrostu siewek
}

\author{
Evaluation of onion (Allium cepa L.) accessions for drought tolerance at \\ germination and seedling growth
}

Urszula Kłosińska®

Pracownia Genetyki i Hodowli Roślin Warzywnych, Instytut Ogrodnictwa, ul. Konstytucji 3 Maja 1/3, 96-100 Skierniewice

e-mail: urszula.klosinska@inhort.pl

\begin{abstract}
Celem badań była ocena wpływu niedoboru wody na zdolność kiełkowania nasion i wzrost siewek cebuli oraz identyfikacja obiecujących obiektów do wykorzystania w przyszłych programach hodowli nowych odmian cebuli tolerancyjnych na stres suszy. Oceniono 150 linii/odmian cebuli pochodzących z polskich i zagranicznych firm hodowlano-nasiennych oraz z Banku Genów Instytutu Ogrodnictwa w Skierniewicach. Doświadczenia prowadzono $\mathrm{w}$ warunkach laboratoryjnych indukując stres suszy przez zastosowanie $18 \%$ poliglikolu etylenowego $\left(\mathrm{PEG}_{8000}\right)$ w fazie kiełkowania nasion i 10\% PEG w fazie siewek. Badane obiekty cebuli wykazały istotne zróżnicowanie pod względem tolerancji na stres suszy, potwierdzone wysokimi wartościami współczynnika zmienności (CV) dla ocenianych parametrów: maksymalny procent skiełkowanych nasion $(35,3 \%)$, świeża masa siewek $(38,5 \%)$, długość liścieni siewek $(42,9 \%)$ i długość korzeni siewek (56,3\%). Zanotowano, że niedobór wody najmniej ograniczył kiełkowanie nasion o 23\%, następnie długość korzeni o 36\%, a najbardziej świeżą masę siewek i długość liścieni, odpowiednio o $52 \%$ i 53,5\%. Stwierdzono silną korelację $(\mathrm{r}=0,81-0,86)$ między cechami opisującymi wzrost siewek w warunkach suszy, wskazując, że deficyt wody redukuje wzrost całych siewek. Natomiast zależności pomiędzy nimi a kiełkowaniem w stresie suszy okazały się nieistotne $(\mathrm{r}=0,19-0,24)$. Spośród 150 obiektów cebuli, genotyp 171026 wykazał wysoki poziom tolerancji na suszę zarówno w fazie kiełkowania, jak i w fazie siewek.
\end{abstract}

Słowa kluczowe: Allium cepa, glikol polietylenowy (PEG), niedobór wody, tolerancja

The aim of this study was to assess the effect of water deficiency on germination ability and growth of onion seedlings, and identify promising accessions for use in future breeding programs of new onion varieties with drought tolerance. We evaluated 150 onion lines/cultivars derived from Polish and foreign breeding and seed companies and from the Gene Bank of the Institute of Horticulture in Skierniewice. Experiments were performed under laboratory conditions inducing drought stress by using $18 \%$ polyethylene glycol $\left(\mathrm{PEG}_{8000}\right)$ in the seed germination phase and $10 \%$ PEG in the seedling phase. Significant differences in reaction to drought stress were observed among onion accessions, confirmed by the high values of the coefficient of variation (CV) for the assessed parameters: maximum percentage of germinated seeds $(35,3 \%)$, fresh weight of seedling $(38,5 \%)$, cotyledons length of seedling $(42,9 \%)$ and root length of seedling $(56,3 \%)$. The received results showed, that water deficiency reduced seed germination the least by $23 \%$, then the root length by $36 \%$, and the fresh weight of seedling and cotyledon length by $52 \%$ and $53,5 \%$, respectively. A high correlation $(\mathrm{r}=0,81-0,86)$ between the features describing the growth of seedlings under drought conditions was found, indicating that water deficit reduced growth of whole seedlings. However, no correlation $(r=0,19-0,24)$ between them and germination under drought conditions was observed. Among 150 onion accessions, genotype 171026 showed a high level of drought tolerance, both in seed germination stage and in seedling growth stage.

Keywords: Allium cepa, polyethylene glycol (PEG), tolerance, water deficit

\section{Wstęp}

Cebula należy do gatunków warzyw o największym znaczeniu pod względem wielkości produkcji, zarówno w Polsce, jak i na świecie. Polska $\mathrm{z}$ rocznymi plonami przekraczającymi 650 tysięcy ton, jest trzecim producentem cebuli w UE, po Holandii i Hiszpanii (EUROSTAT 2017). Pod względem areału uprawy warzyw w naszym kraju, cebula zajmuje pierwsze miejsce (GUS 2018). Gatunek ten jest szczególnie wrażliwy na stres suszy $\mathrm{w}$ fazie kiełkowania nasion i wschodów oraz $\mathrm{w}$ fazie wiązania i przyrostu cebul (Addai i in., 2014; Hanci i Cebeci, 2015). Niedobór wody występujący w fazie kiełkowania nasion powoduje opóźnienie wschodów, zmniejszenie liczby roślin na jednostce powierzchni, a w konsekwencji obniżenie plonu. Okresy suszy występujące przed i w trakcie wiązania, a następnie przyrostu cebul prowadzą do zahamowania ich wzrostu, skutkując nie tylko 
redukcją wysokości plonu, ale także obniżeniem jakości przechowalniczej. Najlepszą metodą zabezpieczającą uprawy cebuli przed negatywnymi skutkami suszy jest hodowla odmian o podwyższonej tolerancji na stres niedoboru wody. Jest to szczególnie ważne w związku z prognozowanym wzrostem deficytu wody wskutek postępujących zmian klimatu (Ziernicka-Wojtaszek, 2015).

W ostatnim czasie podjęto w Instytucie Ogrodnictwa (IO) w Skierniewicach badania, których pierwszym etapem było opracowanie metody testowania cebuli $\mathrm{w}$ fazie kiełkowania nasion i wzrostu siewek przy użyciu glikolu polietylenowego (PEG) - substancji osmotycznie czynnej obniżającej potencjał wody (Michel, 1983). PEG jest polimerem indukującym stres osmotyczny w warunkach in vitro powszechnie stosowanym $\mathrm{w}$ testach tolerancji różnych gatunków roślin na niedobór wody: kukurydzy (Hohl i Schopfer, 1991), sosny (Zhu i in., 2006), pszenicy (Kolasińska, 2009), sorga (Bibi $\mathrm{i}$ in., 2012), ryżu (Wang $\mathrm{i}$ in., 2013), soczewicy (Muscolo i in., 2014), pomidora (Brdar-Jokanović i Zdravković, 2015) i ogórka (Kłosińska i in., 2016).

Biorąc pod uwagę szeroką pulę zarejestrowanych odmian cebuli (Rejestr COBORU odnotowuje 57 odmian, a rejestr EU - ok. 1200 odmian) oraz kolekcję tego gatunku w Banku Genów IO, istnieje duże prawdopodobieństwo identyfikacji materiałów o wysokiej tolerancji na deficyt wody. Dlatego też podjęto badania, których celem była ocena kiełkowania nasion i wzrostu siewek 150 linii/odmian cebuli różnego pochodzenia w warunkach symulowanej suszy przy użyciu PEG.

\section{Material i Metody}

Materiałem badawczym było 150 obiektów pochodzących z polskich i zagranicznych firm hodowlano-nasiennych oraz $\mathrm{z}$ Banku Genów Instytutu Ogrodnictwa w Skierniewicach (tab. 1). Badania przeprowadzono w roku $2019 \mathrm{w}$ fazie kiełkowania nasion oraz w fazie siewek w warunkach laboratoryjnych. Stres suszy indukowano przez zastosowanie poliglikolu etylenowego $\left(\mathrm{PEG}_{8000}\right)$ obniżającego potencjał wody według metody zoptymalizowanej w Instytucie Ogrodnictwa w Skierniewicach (Kłosińska i in., 2019).

\section{Faza kietkowania nasion}

Nasiona 150 obiektów cebuli wykładano do szalek wyłożonych bibułą nasączoną $4 \mathrm{ml}$ PEG

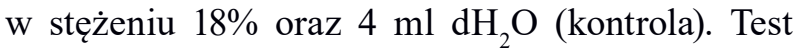
przeprowadzono w 3 powtórzeniach, w każdym po 50 nasion $\times 2$ kombinacje $\left(18 \%\right.$ PEG i $\left.\mathrm{dH}_{2} \mathrm{O}\right)$. Szalki umieszczono w ciemności w fitotronie w temperaturze $18^{\circ} \mathrm{C}$. Na podstawie liczby skiełkowanych nasion notowanych codziennie od wysiewu przez 14 dni, obliczono: wskaźnik gMAX (maksymalny\% skiełkowanych nasion), oraz procent skiełkowanych nasion w 18\% PEG w odniesieniu do kontroli.

\section{Faza siewek}

Skiełkowane nasiona (dł. 10-15 mm) 150 obiektów cebuli wykładano do szalek wyłożonych bibułą nasączoną $4 \mathrm{ml}$ PEG w stężeniu $10 \%$ oraz $4 \mathrm{ml}$ $\mathrm{dH}_{2} \mathrm{O}$ (kontrola). Test przeprowadzono w 3 powtórzeniach, w każdym po 10 nasion $\times 2$ kombinacje

Pochodzenie i liczebność badanych obiektów cebuli

Origin and accessions number of onion used in study

\begin{tabular}{c|c}
\hline $\begin{array}{c}\text { Pochodzenie } \\
\text { Origin }\end{array}$ & $\begin{array}{c}\text { Liczba obiektów } \\
\text { Accessions number }\end{array}$ \\
\hline „Pice & 34 \\
„Polan”, Kraków & 22 \\
"Plantico", Zielonki & 59 \\
„Spójnia", Nochowo & 20 \\
PNOS, Ożarów Mazowiecki & 2 \\
Bejo Zaden & 8 \\
Enza Zaden & 2 \\
Nunhems Bayer & 2 \\
Syngenta & 1 \\
\hline
\end{tabular}


$\left(10 \%\right.$ PEG i $\left.\mathrm{dH}_{2} \mathrm{O}\right)$. Szalki umieszczono w fitotronie typu walk-in w temperaturze $24^{\circ} \mathrm{C} /$ dzień i $20^{\circ} \mathrm{C} /$ noc oraz $12 \mathrm{~h}$ fotoperiodzie. Po 12 dniach wykonano pomiary długości korzenia i liścieni oraz świeżej masy.

Wykonano zestawienie uzyskanych wyników, obliczając średnie arytmetyczne dla cech badanych odmian w warunkach kontrolnych i stresowych. Oddzielnie dla każdej linii/odmiany przeprowadzono analizę wpływu deficytu wody na wielkość badanych parametrów wyrażoną $\mathrm{w}$ procentach względem kontroli oraz obliczono współczynnik zmienności (CV) i współczynnik korelacji (r).

\section{Wyniki i Dyskusja}

Proces kiełkowania i wzrost siewek to najbardziej krytyczne fazy w cyklu życiowym roślin (Ahmed i in., 2009). Narażenie nasion na niekorzystne warunki takie jak susza ma destrukcyjny wpływ na wykształcanie siewek i często dalszy przebieg rozwoju roślin (Albuquerque i Carvalho, 2003). W celu symulacji suszy, w niniejszych badaniach w fazie kiełkowania cebuli zastosowano 18\% PEG, natomiast w fazie siewek - 10\% PEG. Substancje te w znaczny sposób obniżyły zdolność kiełkowania nasion (tab. 2), a także zahamowały wzrost siewek (tab. 3). Badane obiekty cebuli istotnie różniły pod względem tolerancji na niedobór wody, co potwierdzają wysokie wartości współczynnika zmienności (CV) dla ocenianych parametrów: maksymalny procent skiełkowanych nasion $(35,3 \%)$, świeża masa siewek $(38,5 \%)$, długość liścieni siewek $(42,9 \%)$ i długość korzeni siewek $(56,3 \%)$ (tab. 2, 3).

Nasiona 150 testowanych odmian/linii cebuli odznaczały się dobrą zdolnością kiełkowania w warunkach kontrolnych ( $0 \%$ PEG), o czym świadczy średnia wartość parametru gMAX (maksymalny\% kiełkowania nasion) wynosząca 76,1\% (tab. 2). Zastosowany w niniejszych badaniach 18\% PEG

Tabela 2

Table 2

Maksymalny\% kiełkowania nasion (gMAX) 150 obiektów cebuli w warunkach kontrolnych (0\% PEG) i stresu suszy (18\% PEG) oraz liczba skiełkowanych nasion w 18\% PEG względem kontroli w\%

Maximum\% of seed germination (gMAX) of 150 onion accessions under control treatment (0\% PEG) and drought stress (18\% PEG); and number of seed germinated under $18 \%$ PEG treatment relative to control in $\%$

\begin{tabular}{c|c|c|c}
\hline \multirow{2}{*}{$\begin{array}{c}\text { Parametr } \\
\text { Parameter }\end{array}$} & \multicolumn{2}{|c|}{ gMAX (\%) } & \multirow{2}{*}{$\begin{array}{c}\text { \% kontroli } \\
\% \text { control }\end{array}$} \\
\cline { 2 - 3 } & $\begin{array}{c}\text { kontrola } \\
\text { control }\end{array}$ & $\begin{array}{c}\text { stres } \\
\text { stress }\end{array}$ & con \\
\hline $\begin{array}{c}\text { Średnia } \\
\text { Mean }\end{array}$ & 76,1 & 58,6 & 77,0 \\
$\begin{array}{c}\text { Zakres } \\
\text { Range }\end{array}$ & $11,3-100$ & $4,7-96,7$ & $7,5-139,3$ \\
CV* $(\%)$ & 23,0 & 35,3 & 30,0 \\
\hline
\end{tabular}

*wspótczynnik zmiennosici; the coefficient of variation

Tabela 3

Table 3

Świeża masa, długość liścieni i długość korzeni siewek 150 obiektów cebuli w warunkach kontrolnych (0\% PEG) i stresu suszy (10\% PEG) oraz wartości tych parametrów w 18\% PEG względem kontroli w\%

Fresh weight, cotyledons length and root length of seedlings of 150 onion accessions under the control treatment $(0 \%$ PEG) and drought stress (10\% PEG); and values of these parameters under the 10\% PEG treatment relative to control in $\%$

\begin{tabular}{|c|c|c|c|c|c|c|c|c|c|}
\hline \multirow{2}{*}{$\begin{array}{l}\text { Parametr } \\
\text { Parameter }\end{array}$} & \multicolumn{3}{|c|}{$\begin{array}{c}\text { Świeża masa siewek } \\
\text { Fresh weight of seedlings }\end{array}$} & \multicolumn{3}{|c|}{$\begin{array}{c}\text { Długość liścieni siewek } \\
\text { Cotyledons length of seedlings }\end{array}$} & \multicolumn{3}{|c|}{$\begin{array}{l}\text { Długość korzeni siewek } \\
\text { Root length of seedlings }\end{array}$} \\
\hline & $\begin{array}{l}\text { kontrola } \\
\text { control } \\
(\mathrm{mg})\end{array}$ & $\begin{array}{l}\text { stres } \\
\text { stress } \\
(\mathrm{mg})\end{array}$ & $\begin{array}{l}\% \text { kontroli } \\
\% \text { control }\end{array}$ & $\begin{array}{l}\text { kontrola } \\
\text { control } \\
(\mathrm{cm})\end{array}$ & $\begin{array}{l}\text { stres } \\
\text { stress } \\
(\mathrm{cm})\end{array}$ & $\begin{array}{l}\% \text { kontroli } \\
\% \text { control }\end{array}$ & $\begin{array}{c}\text { kontrola } \\
\text { control } \\
(\mathrm{cm})\end{array}$ & $\begin{array}{l}\text { stres } \\
\text { stress } \\
(\mathrm{cm})\end{array}$ & $\begin{array}{l}\% \text { kontroli } \\
\% \text { control }\end{array}$ \\
\hline $\begin{array}{l}\text { Średnia } \\
\text { Mean }\end{array}$ & 37,0 & 17,5 & 48,1 & 4,8 & 2,2 & 46,5 & 4,3 & 2,7 & 64,0 \\
\hline $\begin{array}{l}\text { Zakres } \\
\text { Range }\end{array}$ & $24,0-55,5$ & $7,4-35,9$ & $19,3-89,6$ & $2,6-7,6$ & $0,7-5,1$ & $15,2-112,1$ & $1,4-7,4$ & $0,5-7,7$ & $16,7-149,5$ \\
\hline $\mathrm{CV}^{*}(\%)$ & 18,8 & 38,5 & 40,6 & 20,3 & 42,9 & 44,8 & 29,6 & 56,3 & 48,1 \\
\hline
\end{tabular}

*wspótczynnik zmiennosici; the coefficient of variation 
został także użyty w badaniach nad ogórkiem przez Zhang i wsp. (2013) oraz Kłosińską i wsp. (2016). Jednakże porównując otrzymane wyniki z wynikami ww. autorów stwierdzono, że cebula jest bardziej wrażliwa na stres suszy w fazie kiełkowania nasion niż ogórek. U sześciu obiektów cebuli zanotowano większy wskaźnik kiełkowania w warunkach stresowych względem kontroli średnio od 10 do 36,3\% (tab. 4), co może wskazywać na ich wysoki poziom tolerancji na suszę. Najbardziej wrażliwe na deficyt wody w fazie kiełkowania okazały się trzy linie, u których\% skiełkowanych nasion po 14 dniach traktowania 18\% PEG mieścił się $\mathrm{w}$ przedziale od 7,5 do 12,7\% w porównaniu do kontroli (tab. 4).

Ze względu na zróżnicowaną siłę wzrostu siewek w warunkach kontrolnych, oddzielnie dla każdej linii/odmiany przeprowadzono analizę wpływu 10\% PEG na wielkość badanych cech w odniesieniu do kontroli. Pozwoliło to na wytypowanie linii charakteryzujących się skrajną reakcją na stres suszy. U 33 genotypów cebuli zanotowano długość korzenia na poziomie $90-149,5 \%$ w stosunku do kontroli, z czego u 14 obiektów długość korzenia w 10\% PEG przekroczyła 110\% kontroli (tab. 4). Na szczególne wyróżnienie zasługują trzy linie: ZS/113, ZS/109 i 171026, których długość korzeni w stresie suszy była wyższa odpowiednio o 49,5, 42,4 i 33,6\% względem kontroli, co może wskazywać na ich wysoki poziom tolerancji na badany stres, zważywszy że również u linii tych odnotowano niewielki spadek świeżej masy. Natomiast największą redukcję długości korzenia, o ponad $80 \%$ w stosunku do kontroli, obserwowano u sześciu obiektów (tab. 4). Badano również wpływ 10\% PEG na długość liścieni siewek cebuli. U dwóch linii ZS/105 i ZS/117 obserwowano wzrost tej cechy odpowiednio o 12 i 11\% względem kontroli, natomiast u pozostałych 148 stres suszy spowodował zahamowanie wzrostu liścieni, które było największe u sześciu linii i przekroczyło $80 \%$ w stosunku do kontroli (tab. 4). Zastosowanie 10\% stężenia PEG także u wszystkich obiektów zmniejszyło świeżą masę siewek. Spośród 150 ocenianych linii najmniejszy stopień redukcji świeżej masy w stosunku do kontroli $(10-24 \%)$ stwierdzono u 12 obiektów, natomiast najwyższy (80\%) u dwóch genotypów NOE/61 i 171009.

$\mathrm{Na}$ podstawie średnich wartości z wszystkich linii stwierdzono, że stres niedoboru wody najmniej ograniczył kiełkowanie nasion - o 23\% (tab. 2), następnie długość korzeni - o 36\%, natomiast świeża masa i długość liścieni były zahamowane odpowiednio o 52 i 53,5\%, co stanowiło 48 i 46,5\% względem kontroli (tab. 3). Wiele doniesień literaturowych podkreśla, że deficyt wodny w podłożu bardziej obniża wzrost części nadziemnej niż wzrost korzeni roślin różnych gatunków: fasoli (Turkan i in., 2004), melona (Tuna i in., 2010), pomidora (Prokic i Stikic, 2012) i sorgo (Bibi in. 2012), co potwierdziły również niniejsze badania dotyczące cebuli. Dlatego też zahamowanie wzrostu części nadziemnej i zwiększenie wzrostu korzeni jest jednym z ważniejszych wskaźników tolerancji na stres suszy.

Wyniki badań sugerują, że takie parametry, jak kiełkowanie nasion, świeża masa siewek, długość korzenia i liścieni mogą być wykorzystane do szybkiej selekcji genotypów tolerancyjnych na stres suszy we wczesnej fazie wzrostu. Na podstawie pozytywnie lub negatywnie wyróżniającego się przynajmniej jednego z ocenianych parametrów, badane linie klasyfikowano jako tolerancyjne lub wrażliwe (tab. 4). Spośród 150 obiektów cebuli, wytypowano 23 linie/odmiany tolerancyjne i 13 wrażliwych, a pozostałe 114 obiektów charakteryzowało się średnim stopniem tolerancji lub wrażliwości na niedobór wody. Najwięcej tolerancyjnych obiektów (14) pochodziło z firmy „Plantico", co może wynikać z dużej liczby testowanych obiektów (59), które stanowiły aż 40\% wszystkich badanych. Na drugiej pozycji uplasowały się tolerancyjne obiekty z Banku Genów (6), natomiast najmniej obiektów tolerancyjnych pochodziło z firm: „Spójnia”, „Polan” i PNOS (tab. 4). Wśród 23 linii tolerancyjnych, aż 20 odznaczało się dobrą i bardzo dobrą zdolnością kiełkowania w stresie suszy wynoszącą od 77,4 do 136,3\% względem kontroli (tab. 4). Jednakże dwie $\mathrm{z}$ nich ZS/131 i 171007 o najwyższych parametrach kiełkowania w warunkach deficytu wody, przewyższających kontrolę odpowiednio o 21,4 i 36,3\%, cechowały się silną redukcją świeżej masy siewek, długości liścieni i korzeni, od 63,3 do 73,4\%. Podobną zależność zaobserwowano u większości linii wrażliwych, które także przy dobrych parametrach kiełkowania od 73,4 do 105,6\% względem kontroli charakteryzowały się silnym zahamowaniem wzrostu siewek. Wśród linii wrażliwych było 6 linii z Banku Genów, po trzy z „Plantico” i „Spójni” oraz jedna z „Polana" (tab. 4). Wytypowane linie ze skrajną reakcją na stres suszy posłużą do badań fizjologicznych i biochemicznych czynników warunkujących tolerancję cebuli na deficyt wody.

W celu poznania zależności pomiędzy badanymi cechami w warunkach stresu suszy obliczono współczynnik korelacji (r) (tab. 5). Stwierdzono silną korelację między świeżą masą siewek a długością ich liścieni i korzeni w warunkach niedoboru wody, 
Tabela 4

Table 4

Charakterystyka tolerancyjnych i wrażliwych obiektów cebuli w warunkach stresu suszy (18\% PEG - faza kiełkowania; 10\% PEG - faza siewek) względem kontroli w\%

Characteristics of tolerant and sensitive onion accessions under drought stress conditions (18\% PEG - germination stage; $10 \%$ PEG - seedlings stage) relative to control in \%

\begin{tabular}{|c|c|c|c|c|c|}
\hline $\begin{array}{c}\text { Obiekt } \\
\text { Accession }\end{array}$ & $\begin{array}{l}\text { Pochodzenie } \\
\text { Origin }\end{array}$ & $\begin{array}{c}\text { Kiełkowanie } \\
\% \text { kontroli } \\
\text { Germination } \\
\% \text { control }\end{array}$ & $\begin{array}{c}\text { Świeża masa siewek } \\
\% \text { kontroli } \\
\text { Fresh weight } \\
\text { of seedlings } \\
\% \text { control }\end{array}$ & $\begin{array}{l}\text { Długość liścieni } \\
\text { siewek \% kontroli } \\
\text { Cotyledons length } \\
\text { of seedlings } \\
\% \text { control } \\
\end{array}$ & $\begin{array}{c}\text { Długość korzeni siewek } \\
\% \text { kontroli } \\
\text { Root length of seedlings } \\
\% \text { control }\end{array}$ \\
\hline \multicolumn{6}{|c|}{$\begin{array}{c}\text { Tolerancyjne } \\
\text { Tolerant }\end{array}$} \\
\hline $\mathrm{ZS} / 105$ & „Plantico”, Zielonki & 80,6 & 80,3 & 112,1 & 124,2 \\
\hline ZS/109 & „Plantico”, Zielonki & 89,1 & 77,5 & 64,4 & 142,4 \\
\hline $\mathrm{ZS} / 110$ & „Plantico”, Zielonki & 100,8 & 75,6 & 64,4 & 121,4 \\
\hline $\mathrm{ZS} / 111$ & „Plantico”, Zielonki & 81,6 & 88,2 & 68,5 & 120,0 \\
\hline $\mathrm{ZS} / 113$ & „Plantico”, Zielonki & 65,3 & 83,0 & 72,8 & 149,5 \\
\hline $\mathrm{ZS} / 115$ & „Plantico”, Zielonki & 90,8 & 37,6 & 81,0 & 112,5 \\
\hline $\mathrm{ZS} / 117$ & „Plantico”, Zielonki & 91,0 & 67,0 & 111,0 & 104,7 \\
\hline $\mathrm{ZS} / 118$ & „Plantico”, Zielonki & 64,1 & 57,4 & 70,7 & 113,2 \\
\hline $\mathrm{ZS} / 119$ & „Plantico”, Zielonki & 81,6 & 69,2 & 90,9 & 120,5 \\
\hline $\mathrm{ZS} / 131$ & „Plantico”, Zielonki & 121,4 & 26,6 & 29,7 & 36,7 \\
\hline $\mathrm{ZS} / 134$ & „Plantico”, Zielonki & 116,7 & 61,8 & 61,5 & 94,7 \\
\hline $\mathrm{ZS} / 135$ & „Plantico”, Zielonki & 112,8 & 57,8 & 69,6 & 84,4 \\
\hline $\mathrm{ZS} / 138$ & „Plantico”, Zielonki & 85,9 & 83,4 & 80,2 & 116,1 \\
\hline $\mathrm{ZS} / 158$ & „Plantico”, Zielonki & 86,2 & 58,6 & 65,2 & 113,9 \\
\hline 171007 & Bank Genów, IO & 136,3 & 29,6 & 31,0 & 33,6 \\
\hline 171011 & Bank Genów, IO & 91,7 & 85,4 & 66,2 & 91,0 \\
\hline 171017 & Bank Genów, IO & 102,4 & 88,7 & 79,0 & 86,1 \\
\hline 171018 & Bank Genów, IO & 103,1 & 89,6 & 79,9 & 116,9 \\
\hline 171026 & Bank Genów, IO & 112,2 & 82,0 & 75,8 & 133,6 \\
\hline 171099 & Bank Genów, IO & 63,5 & 86,8 & 71,9 & 116,9 \\
\hline $\mathrm{NOE} / 64$ & „Spójnia”, Nochowo & 92,6 & 82,2 & 71,9 & 87,9 \\
\hline $\mathrm{P} / 37$ & „Polan”, Kraków & 77,4 & 52,8 & 54,6 & 115,5 \\
\hline Bolero $\mathrm{F}_{1}$ & PNOS, Ożarów Maz. & 115,3 & 39,2 & 35,3 & 40,1 \\
\hline \multicolumn{6}{|c|}{$\begin{array}{l}\text { Wrażliwe } \\
\text { Sensitive }\end{array}$} \\
\hline $\mathrm{ZS} / 46$ & „Plantico”, Zielonki & 8,1 & 53,8 & 49,3 & 36,9 \\
\hline $\mathrm{ZS} / 159$ & „Plantico”, Zielonki & 12,7 & 38,3 & 39,2 & 47,0 \\
\hline $\mathrm{ZS} / 181$ & „Plantico”, Zielonki & 7,5 & 41,4 & 33,8 & 35,3 \\
\hline 171009 & Bank Genów, IO & 73,4 & 19,7 & 15,2 & 18,0 \\
\hline 171035 & Bank Genów, IO & 74,4 & 25,6 & 21,3 & 16,7 \\
\hline 171036 & Bank Genów, IO & 82,6 & 28,3 & 16,4 & 22,1 \\
\hline 171040 & Bank Genów, IO & 105,6 & 25,2 & 18,7 & 24,1 \\
\hline 171042 & Bank Genów, IO & 83,4 & 25,7 & 25,8 & 18,6 \\
\hline 171051 & Bank Genów, IO & 95,7 & 23,5 & 19,0 & 21,5 \\
\hline $\mathrm{NOE} / 59$ & „Spójnia”, Nochowo & 67,5 & 27,9 & 18,7 & 19,9 \\
\hline $\mathrm{NOE} / 60$ & „Spójnia”, Nochowo & 83,4 & 23,4 & 16,9 & 21,3 \\
\hline $\mathrm{NOE} / 61$ & „Spójnia”, Nochowo & 84,9 & 19,3 & 23,0 & 18,2 \\
\hline $\mathrm{P} / 32$ & „Polan”, Kraków & 77,6 & 35,0 & 22,7 & 18,2 \\
\hline
\end{tabular}


Współczynnik korelacji (r) pomiędzy badanymi cechami 150 obiektów cebuli w warunkach stresu suszy (18\% PEG)

Correlation coefficient (r) between the studied features of 150 onion accessions under drought stress conditions (18\% PEG)

\begin{tabular}{c|c|c|c|c}
\hline $\begin{array}{c}\text { Parametr } \\
\text { Parameter }\end{array}$ & $\begin{array}{c}\text { Kiełkowanie } \\
\text { Germination } \\
(\%)\end{array}$ & $\begin{array}{c}\text { Świeża masa siewek } \\
\text { Fresh weight of seedlings } \\
(\mathrm{mg})\end{array}$ & $\begin{array}{c}\text { Długość liścieni siewek } \\
\text { Cotyledons length of } \\
\text { seedlings }(\mathrm{cm})\end{array}$ & $\begin{array}{c}\text { Długość korzeni siewek } \\
\text { Root length of seedlings } \\
(\mathrm{cm})\end{array}$ \\
\hline $\begin{array}{c}\text { Kiełkowanie } \\
\text { Germination (\%) } \\
\text { Świeża masa siewek }\end{array}$ & 1 & $0,2363^{\text {ns }}$ & $0,1919^{\text {ns }}$ & $0,2116^{\text {ns }}$ \\
$\begin{array}{c}\text { Fresh weight of seedlings } \\
(\mathrm{mg})\end{array}$ & $0,2363^{\text {ns }}$ & 1 & $0,8645^{*}$ & $0,8322^{*}$ \\
$\begin{array}{c}\text { Długość liścieni siewek } \\
\text { Cotyledons lenght of } \\
\text { seedlings (cm) }\end{array}$ & $0,1919^{\text {ns }}$ & $0,8645^{*}$ & 1 & $0,8116^{*}$ \\
$\begin{array}{c}\text { Długość korzeni siewek } \\
\text { Root lenght of seedlings } \\
(\mathrm{cm})\end{array}$ & $0,2116^{\text {ns }}$ & $0,8322^{*}$ & $0,8116^{*}$ & 1 \\
\hline
\end{tabular}

*istotne na poziomie $\alpha=0,01$; significant at $\alpha=0,01$ level

o czym świadczą wartości wynoszące odpowiednio 0,8645 i 0,8322 . Zanotowano także istotny związek liścieni z długością korzeni $(0,8116)$. Jest to zgodne z wynikami Kłosińskiej i wsp. (2016), którzy także zaobserwowali tę samą zależność dla siewek ogórka traktowanych 18\% PEG. Podobne wyniki otrzymano dla melona (Kavas i in., 2013). Autorzy stwierdzili silną korelację między długością korzenia a długością części nadziemnej w warunkach suszy. Natomiast zależność pomiędzy kiełkowaniem a parametrami opisującymi wzrost siewek (świeża masa, długość liścieni i korzeni) w stresie deficytu wody okazała się nieistotna. Potwierdzają to niskie wartości współczynnika korelacji wynoszące odpowiednio 0,2363, 0,2116 i 0,1919 (tab. 5). Otrzymane wyniki mogą wskazywać, iż mechanizmy warunkujące tolerancję na stres suszy w fazie kiełkowania są prawdopodobnie inne od tych, które determinują tę cechę w fazie siewek. Podobną hipotezę sformułowała Kłosińska i in. (2016) w przypadku badań dotyczących ogórka.

Dzięki dużej zmienności pod względem tolerancji na deficyt wody, oceniane obiekty będą użyte jako materiał do badań polimorfizmu genomowego cebuli przy wykorzystaniu platformy DArTseq. Uzyskane wyniki pozwoliły także na wskazanie obiektów, które mogą być wykorzystane jako cenny materiał wyjściowy w programach hodowli twórczej nowych odmian cebuli tolerancyjnych na suszę. Do najbardziej tolerancyjnych w fazie kiełkowania nasion zaklasyfikowano sześć linii/odmian: ZS/131, $\mathrm{ZS} / 134, \mathrm{ZS} / 135,171007,171026$ i Bolero $\mathrm{F}_{1}$, a w fazie wzrostu siewek dziewięć: ZS/105, ZS/109, ZS/110, ZS/111, ZS/113, ZS/138, 171018, 171026 i 171099 . Obiekty te pochodziły z firmy „Plantico” i z Banku Genów, a odmiana Bolero $F_{1} z$ firmy PNOS. Na szczególną uwagę zasługuje genotyp 171026, który wyróżnił się wysokim poziomem tolerancji na suszę zarówno w fazie kiełkowania, jak i w fazie siewek.

\section{Wnioski}

1. Badane obiekty cebuli okazały się istotnie zróżnicowane pod względem tolerancji na stres suszy w fazie kiełkowania i wzrostu siewek. Dzięki temu stanowią cenny materiał do genotypowania, a następnie identyfikacji regionów genomu odpowiedzialnych za tolerancję cebuli na deficyt wody.

2. Zwiększenie długości korzenia pod wpływem stresu suszy może być wskaźnikiem tolerancji cebuli na deficyt wody.

3. Stwierdzono silną korelację między świeżą masą siewek a długością ich liścieni i korzeni w warunkach niedoboru wody. Natomiast zależności pomiędzy kiełkowaniem a parametrami opisującymi wzrost siewek (świeża masa, długość liścieni i korzeni) w stresie suszy okazały się nieistotne. Może to wskazywać na zupełnie inne mechanizmy warunkujące tolerancję cebuli w poszczególnych fazach wzrostu.

4. Wytypowano obiekty cebuli, które mogą być cennym materiałem wyjściowym do wykorzystania w programach hodowli cebuli $\mathrm{z}$ tolerancją na stres suszy.

Badania finansowano ześrodków projektu MRiRW: Badania podstawowe na rzecz postepu biologicznego w produkcji roślinnej. Zadanie nr 104. 


\section{Literatura}

Addai, I. K., Takyi, H., Oduro, G. (2014). Influence of Bulb Weight at Planting and Drought Stress on Growth and Development of onion (Allium cepa L.) in the Northern Region of Ghana. British Journal of Applied Science \& Technology, 4 (14): 2125-2135.

Ahmad, S., Ahmad, R., Ashraf, M. Y., Ashraf, M., Waraich, E. A. (2009). Sunflower (Helianthus annuus L.) response to drought stress at germination and growth stages. Pak. J. Bot. 41: 647-654.

Albuquerque, F. M. C. D., Carvalho, N. M. D. (2003). Effect of type of environmental stress on the emergence of sunflower (Helianthus annuus L.), soyabean (Glycine $\max$ L.) Merril) and maize (Zea mays L.) seeds with different levels of vigor. Seed Sci Technol. 31: 65-467.

Bibi, A., Sadaqat, H. A., Tahir, M. H. N., Akram, H. M. (2012). Screening of sorghum (Sorghum bicolor Var Moench) for drought tolerance at seedling stage in polyethylene glycol. J. Anim. Plant Sci, 22 (3): 671-678.

Brdar-Jokanović, M., Zdravković, J. (2015). Germination of tomatoes under PEG-induced drought stress. Ratar. i Povrtar, 52 (3): 108-113.

Hanci, F., Cebeci, E. (2015). Comparison of salinity and drought stress effects on some morphological and physiological parameters in onion (Allium cepa L.) during early growth phase. Bulgarian Journal of Agricultural Science, 21 (6): 1204-1210.

Hohl, M., Schopfer, P. (1991). Water relations of growing maize coleoptiles. Comparison between mannitol and polyethylene glycol 6000 as external osmotica for adjusting turgor pressure. Plant Physiol. 95: 716-722.

Kavas, M., Baloglu, M. C., Akca, O., Kose, F. S., Gorcay, D. (2013). Effect of drought stress on oxidative damage and antioxidant enzyme activity in melon seedlings. Turkish Journal of Biology 37: 491-498.

Kłosińska, U., Kozik, E. U., Treder, W., Klamkowski, K. (2016). Differential effects of drought stress on germination and seedling growth of cucumber accessions. In: Kozik, E. U., Paris, H. S. (eds) Proceedings of Cucurbitaceae 2016. Warsaw: 217-221.

Kłosińska, U., Nowakowska, M., Szczechura, W., Nowak, K., Treder, W., Klamkowski, K., Wójcik, K. (2019). Analiza genetycznych i biochemicznych podstaw tolerancji cebuli (Allium cepa L.) na stres niedoboru wody. Biuletyn Inst. Hodowli i Aklimatyzacji Roślin NR 286: 309-312.
Kolasińska, K. (2009). Wartość siewna i reakcja ziarniaków zbóż jarych wyprodukowanych na ekologicznych plantacjach nasiennych na stres suszy symulowanej glikolem polietylenowym. Biul. Instyt. Hod. i Aklimat. Rośl. Nr 251: 53-66.

Michel, B. E. (1983). Evaluation of the water potentials of solutio of polyethylene glycol 8000 both in the absence and presence of other solutes. Plant Physiol. 72: 66-70.

Muscolo, A., Sidari, M., Anastasi, U., Santonoceto, C., Maggio, A. (2014). Effect of PEG-induced drought stress on seed germination of four lentil genotypes. Journal of Plant Interactions, 9 (1): 354-363.

Prokic, L. J., Stikic, R. (2012). Effects of different drought treatments on root and shoot development of the tomato wildtype and flacca mutant. Arch. Biol. Sci. 63 (4): $1167-1171$.

Tuna, A. L., Kaya, C., Ashraf, M. (2010). Potassium sulfate improves water deficit tolerance in melon plants grown under glasshouse conditions. J Plant Nutr 33: 1276-1286.

Türkan, İ., Bor, M., Özdemir, F., Koca, H. (2004). Differential responses of lipid peroxidation and antioxidants in the leaves of drought tolerant $P$. acutifolius gray and drought-sensitive $P$. vulgaris L. subjected to polyethylene glycol mediated water stress. Plant Sci 168: 223-231.

Wang, H., Ma, J., Li X., Zhang, R., Li, Y. (2013). Study on drought resistance and screening of the drought resistance assessment indexes at germinating stage of rice. Southwest China Journal of Agricultural Sciences, 17 (5): 594-599.

Ziernicka-Wojtaszek, A. (2015). Klimatyczny bilans wodny na obszarze Polski w świetle współczesnych zmian klimatu. Woda-Środowisko-Obszary Wiejskie, T. 15. Z. 4 (52): 93-100.

Zhang, N., Zhao, B., Zhang, H. J., Weeda, S., Yang, C., Yang, Z. C., et al. (2013). Melatonin promotes water-stress tolerance, lateral root formation, and seed germination in cucumber (Cucumis sativus L.). Journal of Pineal Research, 54 (1): 15-23.

Zhu, J., Kang, H., Tan, H., Xu, M. (2006). Effects of drought stresses induced by polyethylene glycol on germination of Pinus sylvestris var. mongolica seeds from natural and plantation forests on sandy land. Journal of Forest Research, 11 (5): 319-328. 